DOI: 10.20472/IAC.2018.039.001

\author{
HASAN AKYER \\ PAMUKKALE UNIVERSITY , Turkey \\ ZEHRA DURAK \\ PAMUKKALE UNIVERSITY, Turkey
}

\title{
OPTIMAL PRODUCTION PLANNING FOR ORGANIC AGRICULTURE PRODUCTS: A CASE STUDY OF TURKEY
}

\begin{abstract}
:
Agricultural sector that has gained importance in the world. Agriculture field is critically important for the economy of every country. Countries accompany different agricultural production strategies in different regions in accordance with their priorities. The population of the world is rapidly increasing so, the need for food is also increasing. Nowadays, organic planting become a popular topic in the world. Organic agricultural production provide healthier food and more environmentally production system. In this study, a production planning model was developed based on Mean-Variance Model for the production of vegetables in Turkey, which has a significant agricultural production potential for the Aegean region. This study gives as a guide way to the manufacturers for the cultivation plans in future seasons.
\end{abstract}

\section{Keywords:}

Agriculture Economy, Organic Production, Agricultural Planning

JEL Classification: A10 